\title{
Intra and Inter-Rater Measurement Reliability of Tibialis Anterior Muscle (TA) Thickness using the Ultrasonography Spring Gauge Technique
}

\author{
Byeong-Hun Hwang, Tae-Jin Jang, In-Cheol Jeon
}

Department of Physical Therapy, College of Life and Health Science, Hoseo University, Smart Healthcare Convergence Research Center, Hoseo University, Asan, Republic of Korea

Purpose: The purpose of the current study was to determine the intra- and inter-rater reliability of muscle thickness measurement of the TA using ultrasonography (US) conducted at different inward pressures of approximately $0.5 \mathrm{~kg}, 1.0 \mathrm{~kg}$, and no pressure control.

Methods: Twenty healthy subjects were recruited for this study. Two different examiners measured the thicknesses of the dominant TA of each subject randomly to assess the intra- and inter-rater reliability. The measurement values were analyzed using the intra-class correlation coefficient (ICC) with a 95\% confidence interval, standard error of measurement, minimal detectable change, and coefficient of variance.

Results: All intra-rater reliability ICC values showed high reliability above 0.9 . Inter-rater reliability ICC values showed high reliability above 0.9 with 0.5 and $1.0 \mathrm{~kg}$ of inward pressure. In contrast, Inter-rater reliability ICC values showed poor reliability (0.23) with no pressure control of inward pressure.

Conclusion: The findings showed that maintaining consistent inward pressure is essential for reliable results when the muscle thickness of the TA is measured by different examiners in a clinical setting.

Keywords: Inter-rater Reliability, Intra-rater Reliability, Spring Gauge, Tibialis anterior, Ultrasonography

\section{서 론}

정상적인 발등굽힘근의 근력은 일상생활에서 걷기, 뛰기와 더불어 다양한 운동 활동을 하기 위해 필수적이다. ${ }^{1,2}$ 걸음속도의 감소, 계단 오르기의 제한, 기능적 활동의 제한은 발등굽힘근의 약화와 밀접한 연관이 있다.2,3 발목관절의 기능적인 운동과 균형능력을 유지하기 위 해 정확한 평가와 관리가 필수적인데, 그 이유는 신경근육계 손상과 노화로 인해 발등굽힘근의 약화가 나타나기 때문이다. ${ }^{4}$ 하지를 구성 하는 여러 근육군(엉덩관절 벌림근/모음근/굽힘근/폄근/안쪽돌림 근/가쪽돌림근, 무릎관절 폄근/굽힘근 그리고 발등굽힘근/발바닥굽 힘근)의 근력측정 연구에서 노인의 낙상에 가장 많은 영향을 미치는 것은 발등굽힘근의 약화인 것으로 밝혀졌다. ${ }^{5}$ 그 결과 감소된 발등굽 힘근 근력측정은 노인들의 기능제한과 낙상을 예상하는 요소로 사 용될 수 있다. ${ }^{6}$
앞정강근은 발등굽힘의 주동근 역할을 하며, 무릎과 발목관절에 안정적인 움직임을 위해서 필수적인 요소이다. 앞정강근은 점프 및 달리기 시 발목관절에서 동적 안정화 역할을 하며 발등굽힘을 할 때 관절의 축(axis)을 일정하게 유지하는 것을 도와주는 기능을 한다.7.8 그러므로 앞정강근의 강화운동은 발목재활의 효과적인 주요 요소 중 하나라고 볼 수 있다. 선행연구에 따르면, 앞정강근의 약화는 걸 음과 일어선 자세에서 발의 안정성을 떨어뜨릴 수 있는 위험요소라 고 정의했다. ${ }^{5,6}$ 앞정강근, 긴발가락폄근 및 긴엄지폄근 사이의 근육 불균형은 발목과 발의 구조손상에 영향을 줄 수 있으며, 발목 움직임 중 발등굽힘의 기능은 앞정강근의 $55 \%$, 긴발가락폄근의 $30 \%$, 긴엄지 폄근의 $15 \%$ 가 기여한다. ${ }^{9}$ 따라서, 앞정강근은 순수한 발등굽힘기능 을 수행하는 근육으로써, 다른 협력근(긴발가락폄근, 긴엄지폄근)에 비교해서 더 강한 힘을 필요로 한다.10,11

초음파는 근육의 두께측정을 위해 사용되며, 가로 단면적을 결정
Received Jul 16, 2021 Revised Aug 16, 2021

Accepted Aug 18, 2021

Corresponding author In-Cheol Jeon

E-mail jeon6984@hoseo.edu
Copylight (C2021 The Korean Society of Physical Therapy

This is an Open Access article distribute under the terms of the Creative Commons Attribution Non-commercial License (https:// creativecommons.org/license/by-nc/4.o.) which permits unrestricted non-commercial use, distribution, and reproduction in any medium, provided the original work is properly cited. 
하기 위해 보편적으로 사용하는 검사 방법이다..$^{2,13}$ 근육의 가로 단면 적은 힘의 발생과 밀접한 연관이 있다. ${ }^{14,15}$ 따라서 근육의 두께와 가로 단면적 그리고 근력은 서로 밀접한 상관관계가 있다. ${ }^{16,17}$ 초음파를 이 용한 근육두께의 측정은 임상 및 연구환경에서 많이 활용되고 있 다. ${ }^{18}$ 자기공명영상(MRI)과 컴퓨터단층촬영(CT)이 근육의 볼륨을 측 정하기 위해 많이 사용된다. ${ }^{19}$ 초음파 또한 근육의 두께 측정을 위해 사용이 점점 증가하는 추세이다. 그 이유는 초음파가 근육조직을 시 각화 할 수 있는 자기공명영상, 컴퓨터단층촬영과 비슷한 장점을 가 지고 있기 때문이다. ${ }^{3}$ 자기공명영상과 컴퓨터단층촬영을 사용하는 것이 신체조직을 검사하는 가장 적절한 방법이지만, 컴퓨터단층촬영 의 경우 방사선의 노출이 발생되며, 자기공명영상과 같은 정밀측정 기법은 시간이 오래 걸리고, 비싸며, 높은 방사선 수치가 포함되어 있 다는 단점이 있다. ${ }^{20}$

따라서 다양한 선행연구에서 초음파를 이용한 근육의 두께와 가 로 단면적 측정에 대한 연구가 많이 진행되어 왔다. ${ }^{12,13}$ 특히 엉덩허리 근과 긴목근 같은 안정화 근육을 측정한 두 명의 다른 검사자에 대해 높은 측정자 간, 측정자 내 신뢰도가 입증되었다고 보고되었다. ${ }^{21,22}$ 여 러 검사자가 초음파를 이용하여 근육의 두께를 측정할 때, 도자의 일 관된 위치 및 방향은 근육 섬유 방향에 수직 또는 평행하게 배치한 후 측정하는 것이 해상도(resolution)를 일정하게 만드는 중요한 요소 라고 볼수 있다. ${ }^{21}$ 또한, 검사의 신뢰도를 높이기 위해 근육 섬유를 측 정하는 도자가 피부에 닿을 때 발생하는 내부압력을 일정하게 유지 해야 한다. ${ }^{23}$ 내부압력의 경우 근육섬유가 두꺼울수록 내부로 전달되 는 압력에 따라 근육 두께 및 단면적에 영향을 크게 미치기 때문에, minimal detectable change (MDC) 값이 증가해 미세한 차이를 감지하 기 어렵다. ${ }^{21-23}$ 따라서, 이러한 필수요소가 지켜지지 않는 경우 초음파 를 이용한 근육측정에서 측정 알고리즘이 잘못 계산되어 측정 자체 가 부정확할 수 있다. 초음파는 측정하려는 부위에 따라 신뢰도가 바 뀔 수 있다. 지금까지의 연구를 살펴보면, 초음파를 사용하여 다른 두 명의 측정자에 의해 측정된 경우 앞정강근 근육두께 측정을 위해 도 자의 서로 다른 내부압력이 미치는 영향을 조사한 연구는 없었다.

측정자 내 신뢰도는 개인이 선호하는 압력이 일정하기 때문에 압 력이 조절되었을 때와 조절되지 않았을 때가 통계학적으로 유의한 차이가 없을 것이고, 측정자 간 신뢰도는 각 검사자가 가하는 선호 압 력이 다르기 때문에 스프링 게이지로 압력이 조절되었을 때와 조절 되지 않았을 때가 통계학적으로 유의한 차이가 있을 것으로 설정하 였다. 따라서, 본 연구의 목적은 스프링 게이지로 압력을 일정하게 유 지하거나 압력조절을 하지 않고 초음파로 앞정강근의 두께를 측정할 때 측정자간, 측정자 내 신뢰도를 비교하고자 한다.

\section{연구 방법}

\section{1. 연구대상}

20 대 건강한 20 명이 본 연구를 위하여 자발적으로 참여하였다. 본 연구에 참여한 대상자들은 실험 전 모두 자발적 참여 동의서에 서명 하였다. 대상자들의 평균 연령은 21 세이고 몸무게의 평균은 $52.6 \mathrm{~kg}$ 이 며 신장은 $160.3 \mathrm{~cm}$ 이다. 연구대상자의 선정기준은 앞정강근의 문제 가 없는 건강한 사람을 선정하였고 다리마비환자, 그리고 실험과정 중 안쪽번짐, 발등굽힘에 대한 통증이 있는 사람은 제외하였다.

\section{2. 측정도구 및 방법}

초음파 사진은 초음파를 사용한 경험이 2 년 이상인 두 명의 측정 자에서 수집되었다. 근육두께 측정을 위한 $10 \mathrm{MHz}$ 의 선형 도자 초음 파(SG HEALTHCARE Q30, Seoul, Korea)를 사용하였고, 초음파의 도 자가 대상자와 일직선이 되도록 놓고, 주황색 지표가 대상자의 머리 방향으로 향하게 하였다. 근육의 단면적을 측정할 때에는 초음파 도 자는 대상자의 몸과 수직 방향으로 놓았다(Figure 1). 내부압력 $(0.5 \mathrm{~kg}$, $1.0 \mathrm{~kg}$ )을 일정하게 조절하기 위해 스프링 게이지(Kirin Co., Ltd., Seoul, Korea)를 사용하였다. 이 기기는 0.0 부터 $30.0 \mathrm{~kg}$ 까지 측정 가능하며 $0.1 \mathrm{~kg}$ 의 눈금을 갖고 있었다. 비탄력벨트(BSN Medical, Hamburg, Germany)를 이용하여 도자와 스프링 게이지의 끝부분을 연결시켰다.

\section{3. 실험절차}

대상자들은 높이 조절이 가능한 테이블에 바로 눕게 하였다. 각각 의 다른 내부압력을 적용하기 위해 높이 조절 테이블을 이용하여 도 자가 피부에 닿았을 때의 내부압력을 $0 \mathrm{~kg}$ 으로 설정했다. 대상자의 팔은 가슴 앞에 깍지를 끼워 놓도록 했고(Figure 1), 측정을 위해 종아

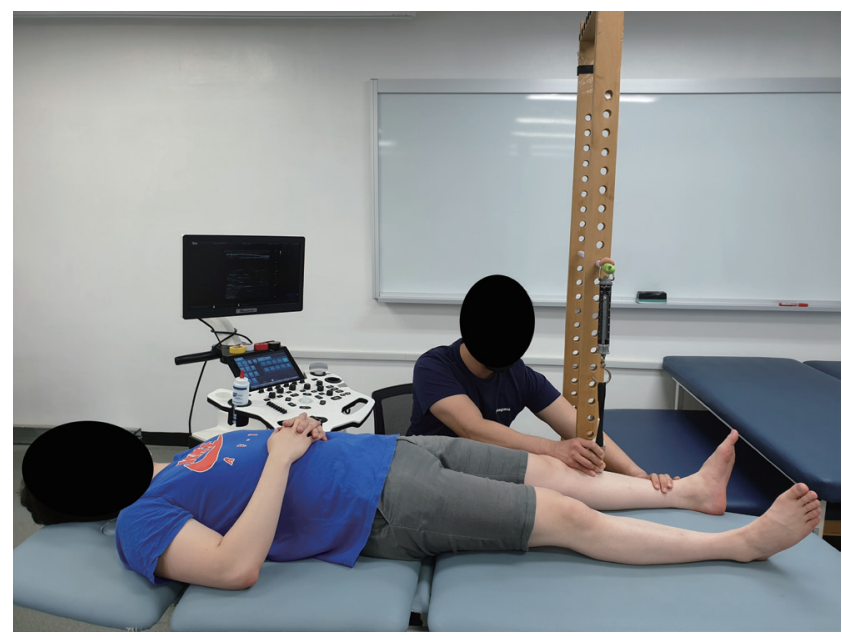

Figure 1. Measurement performed with a handheld ultrasonography transducer and spring gauge. 
리 부위 밑에 견고한 플레이트를 받쳐 놓았다. 앞정강근을 일관적이 게 관찰하며, 스프링 게이지 없이 내부압력이 조절되지 않은 측정(No pressure control)과 스프링 게이지를 이용하여 내부압력이 조절된 측 정을 적용했다. 도자를 앞정강근의 근육섬유방향에 평행하게 위치 시키고, 발목과 무릎 사이 거리의 $50 \%$ 지점 부근에 앞정강근이 가장 두꺼운 부위를 표시한 후 초음파 도자를 이용하여 근육의 두께를 측 정하였다. 초음파로 촬영된 앞정강근의 사진은 계산을 위해 저장되 었다. 근육두께는 각각 다른 내부압력상태에서 세 번의 측정 평균값 으로 계산되었다. 측정자 1 과 측정자 2 의 측정 순서와 내부압력은 무 작위화 하였다. 모든 측정은 측정자 간, 측정자 내 신뢰도를 평가하기 위해 같은 날 수행되었다(Figure 2). 측정자는 측정값 및 대상자 정보 에 대해 모르게 실시되었다.

\section{4. 자료분석}

통계분석은 Statistical Analysis 통계 분석 방법이다. SPSS ver. 18.0 소 프트웨어(SPSS Inc., Chicago, IL, USA)를 사용하고, 급내 상관 계수 (ICC)와 $95 \%$ 신뢰구간(CI)이 사용하며 통계적 유의수준은 0.05 로 설
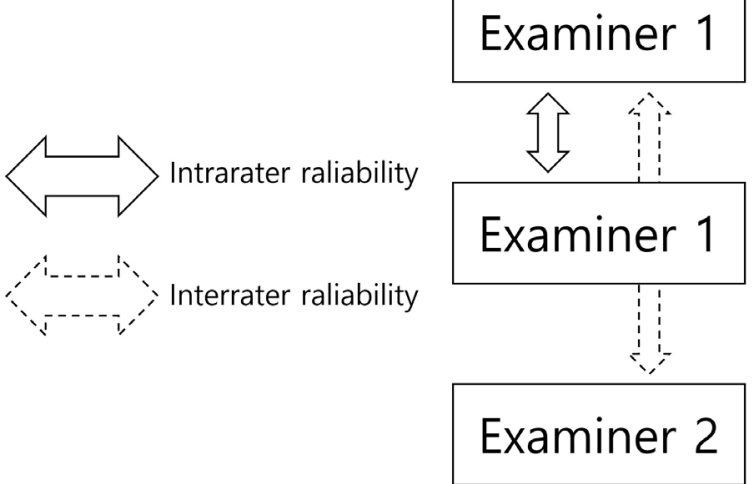

Figure 2. Flow chart of the measurement progression.
정하였다. $\operatorname{ICC}(3,3)$ 모델을 사용하여 측정자내 신뢰도를 측정하고 $\operatorname{ICC}(2,3)$ 모델은 측정자 간의 신뢰도를 측정하기 위해 사용하였다 (Figure 2). 각 상태의 근육두께를 확인하기 위해 동일한 대상자 20명 을 각각 세 번의 촬영 후 두께를 계산하여 평균을 내었다. ${ }^{21.23}$ 세번의 근육두께 측정의 표준편차가 매 순서마다 계산되었다. $\mathrm{MDC}$ 는 $[\mathrm{MDC} 95=1.96 \times \mathrm{SEM} \times \sqrt{ } 2]$ 공식을 사용하여 계산되었다. 이것은 $95 \%$ 의 측정의 최소 오차를 초과하는 변화의 크기를 확인하기 위한 것이 다. 압력에 따른 각각의 조건에 따라 측정된 앞정강근의 두께는 본페 로니 사후검정을 통해 통계적 유의 수준을 비교하였다. 통계적 유의 수준은 0.01 로 설정하였다.

\section{결 과}

측정자 내 신뢰도는 압력조절이 되지 않은 상태, 스프링 게이지로 피부에 닿는 내부압력이 각각 $0.5 \mathrm{~kg}, 1 \mathrm{~kg}$ 으로 압력이 조절된 상태에 서 모두 신뢰도가 높았다(ICC 0.96, 0.99, 0.99)(Table 1). 측정자 간 신뢰 도는 압력조절이 되지 않은 상태의 신뢰도가 낮았다(ICC 0.23)(Table 1, Figure 3). 하지만 스프링 게이지로 피부에 닿는 내부압력이 각각 0.5

Table 1. Intra-rater and Inter-rater reliability

\begin{tabular}{ccccc}
\hline & \multicolumn{4}{c}{ Intra-rater reliability } \\
\cline { 2 - 5 } & ICC (95\%Cl) & SEM (mm) & MDC $(\mathrm{mm})$ & CV $(\%)$ \\
\hline No control & $0.96(0.92-0.98)$ & 0.03 & 0.08 & 12 \\
$0.5 \mathrm{~kg}$ & $0.99(0.97-0.99)$ & 0.02 & 0.04 & 11 \\
$1.0 \mathrm{~kg}$ & $0.99(0.98-0.99)$ & 0.02 & 0.04 & 10 \\
\cline { 2 - 5 } & \multicolumn{4}{c}{ Inter-rater reliability } \\
\cline { 2 - 5 } No control & $0.23(-1.08-0.70)$ & 0.28 & 0.77 & 25 \\
$0.5 \mathrm{~kg}$ & $0.83(0.58-0.93)$ & 0.07 & 0.18 & 12 \\
$1.0 \mathrm{~kg}$ & $0.92(0.79-0.97)$ & 0.04 & 0.10 & 10 \\
\hline
\end{tabular}

ICC: intra-class correlation coefficients, Cl: confidence interval, SEM: standard error of measurement, MDC: minimal detectable change, CV: coefficient of variance.
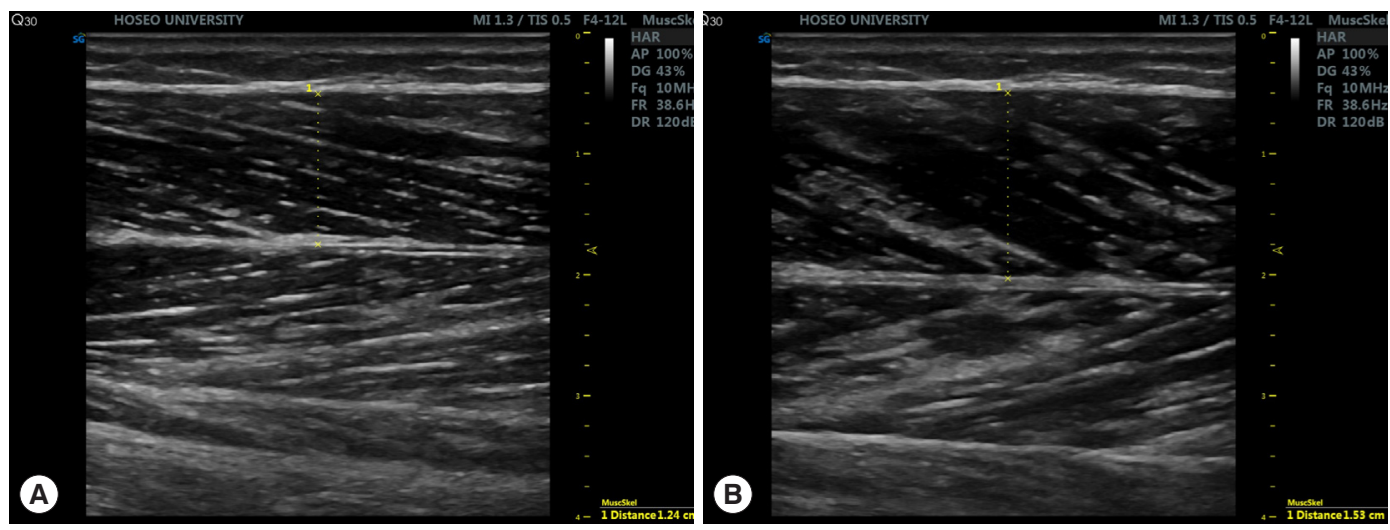

Figure 3. Difference of the TA thickness between examiner 1 (TA thickness $1.24 \mathrm{~cm}$ ) and examiner 2 (TA thickness $1.53 \mathrm{~cm}$ ) with no pressure control in ultrasonographic imaging. 


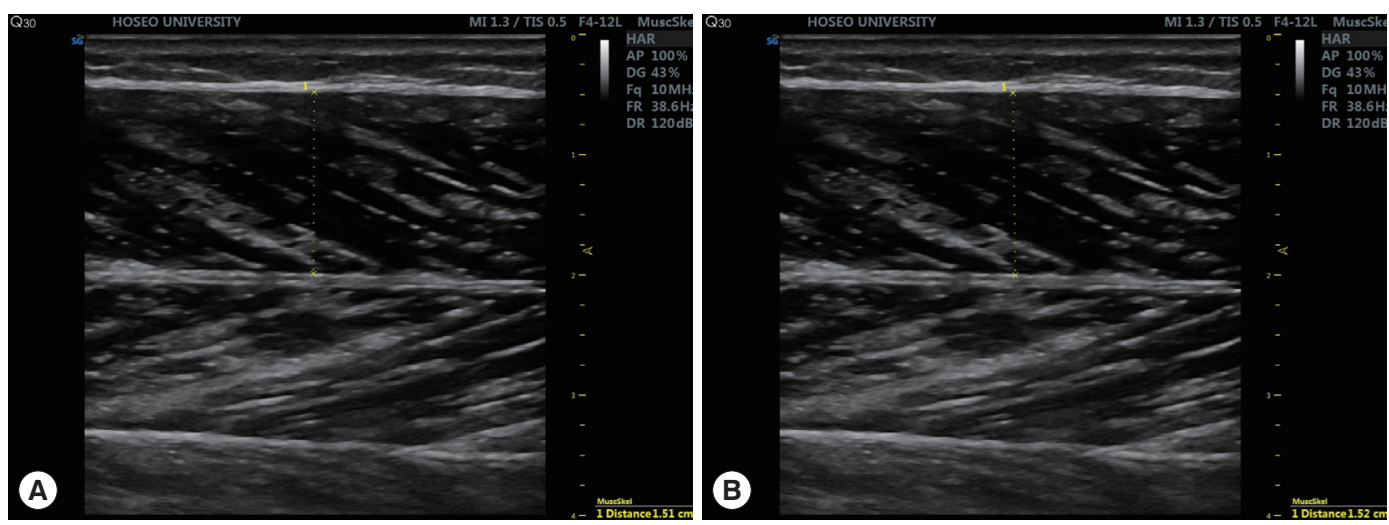

Figure 4. Difference of the TA thickness between examiner 1 (TA thickness $1.51 \mathrm{~cm}$ ) and examiner 2 (TA thickness $1.52 \mathrm{~cm}$ ) with consistent inward pressure control $(1.0 \mathrm{~kg})$ in ultrasonographic imaging.

Table 2. Thickness changes of the TA muscle (cm)

$(n=20)$

\begin{tabular}{ccccc}
\hline & No control & $0.5(\mathrm{~kg})$ & $1.0(\mathrm{~kg})$ & $\mathrm{p}$ value \\
\hline MT of TA & $1.24 \pm 0.32$ & $1.86 \pm 0.16^{\mathrm{a}}$ & $1.52 \pm 0.13^{\mathrm{b}}$ & $<0.01^{\mathrm{c}}$ \\
\hline
\end{tabular}

MT: muscle thickness, TA: tibialis anterior.

aSignificant difference between No control and 0.5 (kg); 'bignificant difference between $0.5(\mathrm{~kg})$ and $1.0(\mathrm{~kg})$; 'Significant difference between conditions.

$p<0.01$

$\mathrm{kg}, 1 \mathrm{~kg}$ 으로 압력이 조절된 상태의 신뢰도는 높았다(ICC $0.83,0.92)$ (Table 1, Figure 4). 그 결과 스프링 게이지로 피부에 닿는 내부압력이 일정하게 조절된 상태에서 앞정강근의 두께를 비교했을 때, 측정자 간, 측정자 내 신뢰도가 모두 높은 것으로 입증되었다. 누르는 압력에 따른 앞정강근의 두께를 비교했을 때, 압력조절이 되지 않은 상태에 서는 $1.24 \pm 0.32 \mathrm{~cm}$ 의 값을 보였고, $0.5 \mathrm{~kg}$ 의 누르는 압력에서는 $1.86 \pm$ $0.16 \mathrm{~cm}$ 의 값을 보였다. 마지막으로 $1.0 \mathrm{~kg}$ 의 누르는 압력에서는 $1.52 \pm$ $0.13 \mathrm{~cm}$ 의 두께를 보였고, 사후 검정에서도 통계학적으로 유의한 차 이를 확인하였다 $(\mathrm{p}<0.01)($ Table 2$)$. 신뢰도의 해석을 위해 ICC값이 0.75를 초과할 경우 excellent, $0.4-0.75$ 인 경우 fair to good, 0.0-0.4인 경 우 poor의 등급이 측정되었다. ${ }^{24}$

\section{고 찰}

본 연구의 목적은 스프링 게이지를 이용하여 내부압력이 조절된 상태와 조절되지 않은 상태에서 초음파로 앞정강근의 두께를 측정했 을 때 측정자 내 신뢰도와 측정자 간 신뢰도를 비교하는 것이다. 측정 자 내 신뢰도는 스프링 게이지를 이용하여 내부압력이 조절된 상태 와 스프링 게이지 없이 조절되지 않은 상태에서의 신뢰도가 통계학 적으로 유의미한 차이가 있지 않았다. 하지만 측정자 간 신뢰도는 스 프링 게이지를 이용하여 내부압력이 조절된 상태와 스프링 게이지 없이 조절되지 않은 상태에서의 측정이 통계학적으로 유의미한차이
가 있었다.

이 연구의 높은 신뢰도는 다양한 구성 요소를 사용하여 측정의 표 준화를 위한 실험 프로토콜에 의해 영향을 받았다. 높이 조절 테이 블은 다른 내부압력에 맞게 앞정강근의 피부표면과 접촉하는 도자 의 높이를 정확하게 조절하기 위해 사용되었고, 도자와 앞정강근의 피부표면 사이 일관된 압력의 접촉 모멘트를 얻을 수 있었다. 게다가 대상자의 다리에 닿는 테이블의 표면이 딱딱하여 도자의 누르는 힘 에 의한 신체위치의 변화를 최소화할 수 있었다. 스프링 게이지는 다 른 내부압력으로 앞정강근의 두께를 측정하는 동안 일관된 압력을 유지하기 위해 사용되었다. 또한 스프링 게이지의 과도한 사용으로 인한 스프링의 탄력성 손실을 방지하기 위해 5 명의 대상자를 측정한 후 스프링 게이지를 다른 스프링 게이지로 교체하였다.25 설명된 다양 한 구성 요소를 사용하여 일관된 내부압력을 유지했기 때문에 높은 측정자 간, 측정자 내 신뢰도를 확인할 수 있었다.

근육의 탄력성은 두께를 정확하게 측정할 때 영향을 준다. ${ }^{26}$ 따라 서 앞정강근 뿐만 아니라 초음파를 이용해 다른 모든 근육의 두께를 측정할 때 일관된 내부압력을 유지하려는 노력이 중요한 요소가 될 수 있다. 근육 두께를 측정할 때 도자의 누르는 내부압력이 일정하지 않다면 잘못된 측정을 할 수 있다. ${ }^{27}$ 그러한 이유로 다양한 근육의 두 께 측정은 내부압력을 일정하게 만들기 위해 High-density foam cube $^{28}$, Transducer holder ${ }^{26}$ 와 같은 장비가 긍정적인 영향을 주었다.

선행연구에서 스프링 게이지는 내부압력을 일정하게 유지하여 근 육의 두께를 일관되게 측정할 수 있는 장점을 가지고 있기 때문에 임 상환경과 연구환경에서 모두 사용될 수 있다고 보고되었다.1721 스프 링 게이지에 대한 최근 연구는 고정된 물체 위에 올려져 있는 동안 한 손으로 조작함과 동시에 압력을 설정할 수 있도록 사용되었다. 또한 압력 확인을 위한 힘 측정판과 같은 추가적인 기기들이 필요하지 않 다. 게다가 스프링 게이지는 비용 효율성과 적용 용이성의 장점이 있 다. 이러한 특징들은 임상환경에서 많이 사용될 수 있으며, 근육의 두 
께를 측정할 때, 내부압력이 일정하지 않아 발생할 수 있는 오류 가능 성을 최소화할수 있다.

선행연구를 보면 압력을 조절하여 초음파로 몸통 근육 두께를 측 정할 때, 다른 근육들보다 배바깥빗근과 허리뭇갈래근의 두께 변화 가 많이 발생했다. ${ }^{29}$ 그 이유는 배바깥빗근이나 허리뭇갈래근은 목표 근육과 도자 사이의 표피 조직의 두께가 배가로근과 배속빗근 근육 들보다 얇기 때문이다. 압력을 조절하여 초음파로 근육 두께를 측정 할 때, 배가로근과 배속빗근의 두께 변화가 적게 관찰될 수 있었던 것 은 목표 근육들과 도자 사이에 배바깥빗근이 존재하기 때문이다. 허 리뭇갈래근의 경우 목표 근육 아래의 척추뼈로부터 반발력(reaction force)이 있었기 때문에, 누르는 압력에 더 민감했다. ${ }^{29}$ 마찬가지로, 이 연구결과에서 앞정강근의 두께를 측정할 때 누르는 압력에 민감한 결과를 보였는데, 해당 근육 또한 초음파 도자의 접촉면으로부터 표 피조직의 두께가 얇기 때문이라고 보여진다. 게다가 앞정강근의 아래 쪽 부분에는 정강뼈로부터 반발력이 존재했기 때문에 초음파를 이 용해 근육 두께를 측정할 때 압력에 더 민감한 것으로 해석된다. 목 표 근육 아래 조직의 탄성력은 목표 근육을 초음파로 촬영하는 동안 압력에 대해 더 민감한 영향을 받았다. 도자의 내부압력이 다르게 적 용된다면, 초음파를 촬영할 때 미세한 변화를 감지할 수 없다. 따라 서 두께 측정 변수에 대한 $\mathrm{MDC}$ 값이 중요한 이유이다. 도자의 내부 압력을 일정하게 유지하는 것은 배바깥빗근과 허리뭇갈래근을 중재 를 할 때 발생되는 근육두께의 최소변화를 명확하게 감지하기 위해 요구된다. ${ }^{29}$ 이 연구 결과에서도 마찬가지로 앞정강근의 근육두께의 최소 변화를 명확하게 감지하기 위해서 압력조절이 적용된 초음파 측정이 필요할 것이다. 측정자 내 신뢰도 결과를 봤을 때, 압력 조절 을 하지 않았을 때와 $0.5 \mathrm{~kg}$ 그리고 $1.0 \mathrm{~kg}$ 의 일정한 압력으로 측정했 을 때, $\mathrm{MDC}$ 값이 상당히 낮을 것을 확인할 수 있었다(No control: 0.08/0.5 kg: 0.04/1.0 kg: 0.04). 이것은 같은 측정자가 동일한 근육 두께 를 측정했을 때, 미세한 근육 두께 변화에도 변화값이 있다는 것을 확인할 수 있는 정확도를 말한다. 반면, 측정자 간 신뢰도 결과를 보 면, 압력 조절이 적용된 초음파 측정에서의 $\mathrm{MDC}$ 값보다 압력 조절 이 적용되지 않은 초음파 측정에서 $\mathrm{MDC}$ 값이 상당히 증가된 것을 확인할 수 있다(No control: $0.77 / 0.5 \mathrm{~kg}: 0.18 / 1.0 \mathrm{~kg}: 0.10)$. 이것은 같은 측 정자가 동일한 근육 두께를 측정했을 때, 증가된 또는 감소된 근육 두 께를 감지할 수 있는 반면, 다른 측정자가 동일한 근육 두께를 측정했 을 때, 앞정강근 두께가 $0.77 \mathrm{~mm}$ 이내의 변화에서는 감지하지 못할 수 있다는 것을 의미한다. 또한 coefficient of variance $(\mathrm{CV})$ 의 결과값을 확인해보면, $\mathrm{CV}(\%)$ 값이 클수록 측정 데이터가 일관되지 않거나, 선 형적이지 않고, 측정에 따라 그 측정값이 산발적이라고 볼 수 있다. 측 정자 간 신뢰도 결과에서 압력 조절이 적용되지 않았을 때의 CV (\%) 값이 가장 큰 이유라고 볼 수 있다.
선행연구에 따르면 다리근육의 두께를 스프링 게이지를 이용하여 압력이 일정하게 유지된 네 가지의 상태 $(0.5 \mathrm{~kg}, 1.0 \mathrm{~kg}, 1.5 \mathrm{~kg}, 2.0 \mathrm{~kg})$ 에 서 측정했을 때 측정자 간, 측정자 내 신뢰도가 높게 보고되었다.21 척 추근육의 두께와 생리학적 가로단면적을 스프링 게이지를 이용하여 압력이 일정하게 유지된 두가지의 상태 $(0.5 \mathrm{~kg}, 1.0 \mathrm{~kg})$ 에서 측정했을 때 측정자 간, 측정자 내 신뢰도가 높게 보고되었다. ${ }^{30}$ 또한 엄지벌림 근의 두께 측정에서도 일정하게 압력이 유지된 상태에서의 측정자 간, 측정자 내 신뢰도가 높게 보고되었다. ${ }^{23}$ 그러므로 초음파를 이용 하여 다리근육과 척추근육의 두께 및 가로단면적을 정확하고 신뢰 할 수 있는 측정을 하기 위해서 일정한 내부압력 조절을 적용하여 사 용하는 것이 필요하다.

앞정강근을 초음파를 이용하여 근육의 두께를 측정하는데, 측정 자 간에 측정값이 차이가 발생한다면 임상적으로 정확한 평가와 치 료계획을 세우는 것에 어려움이 있을 수 있다. 하지만 내부압력이 일 정하게 유지된 상태에서 앞정강근의 근육 두께를 측정하면 측정자 간 신뢰도를 높일 수 있기 때문에 여러 명의 평가자가 측정할 때 발생 할 수 있는 측정오차를 최소화시킬 수 있을 것으로 보여진다.

현재 연구에는 몇 가지 제한 사항이 있다. 첫째, 이 연구의 대상자 들 모두 비교적 젊은 나이의 그룹이기 때문에 일반화되기 어렵다. 후 속연구에서는 다양한 연령층뿐만 아니라 환자그룹에서의 추가 연구 가 필요하다. 둘째, 이 연구는 근육이 이완된 상태에서 수행되었다. 그 러므로 후속연구에서는 근육이 수축된 상태에서 수행하는 추가 연 구가 필요하다.

이 연구는 내부압력이 일정하게 유지된 상태에서 초음파를 이용 하여 앞정강근의 두께를 측정했을 때 측정자 내, 측정자 간 신뢰도에 대해 연구했다. 이 연구에 기초하여, 우리는 일정한 내부압력을 유지 하기 위한 노력이 임상환경에서 적용되었을 때, 앞정강근 근육두께 의 신뢰도 있는 결과를 얻을 수 있다고 확인할 수 있었다. 그리고 이 연구는 측정자 간 일정하지 않은 내부압력이 앞정강근 근육두께의 정확한 측정에 악영향을 줄 수 있다는 것을 의미한다. 그러므로, 내부 압력이 일정하게 유지된 상태에서 초음파를 이용하여 앞정강근의 두께를 측정하면, 높은 측정자 내, 측정자 간 신뢰도를 얻을 수 있을 것이다.

\section{ACKNOWLEDGEMENTS}

This research was funded by the university innovation support project of Hoseo University, grant number 221-01. 


\section{REFERENCES}

1. Krause DA, Cloud BA, Forster LA et al. Measurement of ankle dorsiflexion: a comparison of active and passive techniques in multiple positions. J Sport Rehabil. 2011;20(3):333-44.

2. Tiedemann A, Sherrington C, Lord SR. Physiological and psychological predictors of walking speed in older community-dwelling people. Gerontology. 2005;51(6):390-5.

3. Keysor JJ, Dunn JE, Link CL et al. Are foot disorders associated with functional limitation and disability among community-dwelling older adults?. J Aging Health. 2005;17(6):734-52.

4. Burns J, Redmond A, Ouvrier R et al. Quantification of muscle strength and imbalance in neurogenic pes cavus, compared to health controls, using hand-held dynamometry. Foot Ankle Int. 2005;26(7):540-4.

5. Macrae PG, Lacourse M, Moldavon R. Physical performance measures that predict fall status in community-dwelling older adults. J Orthop Sports Phys Ther. 1992;16(3):123-8.

6. Spink MJ, Fotoohabadi MR, Menz HB. Foot and ankle strength assessment using hand-held dynamometry: reliability and age-related differences. Gerontology. 2010;56(6):525-32.

7. Sahrmann SA. Movement system impairment syndromes of the extremities, cervical and thoracic spines. Amsterdam, Elsevier, 2010:53346.

8. Kisner C, Colby LA. Therapeutic Exercise: foundations and techniques. Philadelphia, FA Davis Company, 2012:764-6.

9. Franck WM, Olk A, Hennig FF. Combined rupture of the tibialis anterior and the extensor hallucis longus tendons functional reconstruction. Arch Orthop Trauma Surg. 2005;125(4):277-80.

10. Jeon IC, Jang JH. Comparison of tibialis anterior muscle activity and dorsiflexor strength according to toe postures. JMST. 2020;4(1):13-7.

11. Hislop H, Avers D, Brown M. Daniels and Worthingham's muscle testing: techniques of manual examination and performance testing. Philadelphia, Elsevier, 2013:283-96.

12. Abe T, Kondo M, Kawakami Y et al. Prediction equations for body composition of Japanese adults by b-mode ultrasound. Am J Hum Biol. 1994;6(2):161-70.

13. O'Sullivan C, Bentman S, Bennett K et al. Rehabilitative ultrasound imaging of the lower trapezius muscle: technical description and reliability. J Orthop Sports Phys Ther. 2007;37(10):620-6.

14. Akagi R, Takai Y, Ohta M et al. Muscle volume compared to cross-sectional area is more appropriate for evaluating muscle strength in young and elderly individuals. Age Ageing. 2009;38(5):564-9.

15. Jubrias SA, Odderson IR, Esselman PC et al. Decline in isokinetic force with age: muscle cross-sectional area and specific force. Pflugers Arch. 1997;434(3):246-53.

16. Abe T, Kawakami Y, Suzuki Y et al. Effects of 20 days bed rest on muscle morphology. J Gravit Physiol. 1997;4(1):S10-4.

17. Sipilä S, Suominen H. Ultrasound imaging of the quadriceps muscle in elderly athletes and untrained men. Muscle Nerve. 1991;14(6):527-33.

18. Akbari A, Khorashadizadeh S, Abdi G. The effect of motor control exercise versus general exercise on lumbar local stabilizing muscles thickness: Randomized controlled trial of patients with chronic low back pain. J Back Musculoskelet Rehabil. 2008;21(2):105-12.

19. McGill SM, Santaguida L, Stevens J. Measurement of the trunk musculature from T5 to L5 using MRI scans of 15 young males corrected for muscle fibre orientation. Clin Biomech (Bristol, Avon). 1993;8(4):171-8.

20. Snijder MB, Visser M, Dekker JM et al. The prediction of visceral fat by dual-energy $\mathrm{x}$-ray absorptiometry in the elderly: a comparison with computed tomography and anthropometry. Int J Obes Relat Metab Disord. 2002;26(7):984-93.

21. Jeon IC, Kim YW, Choung SD. Intra- and inter-rater reliability of thickness measurement of the psoas major muscle using the spring gauge technique for the consistent inward pressures on healthy subjects: an ultrasonographic study. Phys Ther Korea. 2013;20(4):65-72.

22. Cagnie B, Derese E, Vandamme L et al. Validity and reliability of ultrasonography for the longus colli in asymptomatic subjects. Man Ther. 2009;14(4):421-6.

23. Jeon, IC, Kim, MH. Reliability of thickness measurements of the abductor hallucis muscle using the spring gauge technique in hallux valgus subjects: an ultrasonographic study. J Kor Phys Ther. 2016;28(2):119-23.

24. Crossley KM, Bennell KL, Cowan SM et al. Analysis of outcome measures for persons with patellofemoral pain: which are reliable and valid? Arch Phys Med Rehabil. 2004;85(5):815-22.

25. Bohannon RW, Andrews AW. Accuracy of spring and strain gauge hand-held dynamometers. J Orthop Sports Phys Ther. 1989;10(8):3235.

26. Ishida $\mathrm{H}$, Watanabe $\mathrm{S}$. Influence of inward pressure of the transducer on lateral abdominal muscle thickness during ultrasound imaging. J Orthop Sports Phys Ther. 2012;42(9):815-8.

27. Akbari A, Khorashadizadeh S, Abdi G. The effect of motor control exercise versus general exercise on lumbar local stabilizing muscles thickness: randomized controlled trial of patients with chronic low back pain. J Back Musculoskelet Rehabil. 2008;21(2):105-12.

28. Bunce SM, Moore AP, Hough AD. M-mode ultrasound: a reliable measure of transversus abdominis thickness?. Clin Biomech (Bristol, Avon). 2002;17(4):315-7.

29. Ishida H, Watanabe S. Influence of inward pressure applied by the transducer on trunk muscle thickness during ultrasound imaging. J Orthop Sports Phys Ther. 2014;19(2):32-7.

30. Jeong BL, Ha SM, Jeon IC et al. Reliability of ultrasonography measurement for the longus colli according to inward probe pressure. J Phys Ther Sci. 2015;27(11):3579-81. 